\title{
The Competency Development Model Based On Performance
}

\author{
Dimas Agung Trisliatanto \\ Master Program Study of Human Resource \\ Development \\ Postgraduate School of Universitas Airlangga \\ Campus B. Jl. Airlangga No. 4-6 Surabaya, \\ Indonesia \\ e-mail : triztanagung90@gmail.com
}

Fahmi Muhammad Az-Zuhri

Master Program Study of Human Resource

Development

Postgraduate School of Universitas Airlangga

Campus B. Jl. Airlangga No. 4-6 Surabaya, Indonesia

e-mail : fahmi.azzuhri@gmail.com

\author{
Falih Suaedi \\ Lecturer of Public Administration \\ Dean Faculty of Social Science and Political \\ Science \\ Universitas Airlangga \\ Campus B. Jl. Dharmawangsa Dalam, Gubeng - \\ Surabaya, Indonesia \\ e-mail : suaedifalih@yahoo.com \\ Teguh Prasetyo \\ Master Program Study of Human Resource \\ Development \\ Postgraduate School of Universitas Airlangga \\ Campus B. Jl. Airlangga No. 4-6 Surabaya, \\ Indonesia \\ e-mail : adesa630@gmail.com
}

Rizka Pranatasari

Master Program Study of Human Resource Development

Postgraduate School of Universitas Airlangga

Campus B. Jl. Airlangga No. 4-6 Surabaya, Indonesia

e-mail : pranatasaririzka@gmail.com

\begin{abstract}
Competency can be defined as behaviours that are shown from employees who have the potential to work consistently and effectively compared with the working average. PT. Aneka Regalindo is a company engaged in manufacturing furniture which seeks to develop a competency model that integrates with the benchmark competency development model in performing their duties and responsibilities effectively. This research was done using the descriptive qualitative method. The results of this study explain that the competency development model based on performance orientation can be identified and analysed to overcome the problem of human resources in the rattan unit of PT. Aneka Regalindo with mapping indicators.
\end{abstract} Keywords: Competency, Competency
Development Model, Performance Orientation

\section{Introduction}

Human resource issues are still in the spotlight, and they are the foundation for a company to still be able to survive in the current era of globalisation in the ASEAN economy. Human resources have a major role in any company's organisational activities. Although they can be supported by the infrastructure and resources' pooled funding, without the support of qualified human resources, the company's activities will not be achieved successfully. This indicates that human resources are the key principal that must be considered at all times. Human resources will determine the successful implementation of the company's activities. Demands that companies have mean that they have to reach, develop and retain qualified human resources. This has become increasingly urgent in accordance with the dynamics of an ever-changing environment.

Changes need to have the support of top management as an important first step. This can come in the form of guidance and support resources such as providing adequate equipment to facilitate the achievement of the objectives to be reached in relation to mentoring, guidance, training and development that will further facilitate the performance objectively. 
Competency development should not only be concentrated on the opportunities that exist but it should also be focused on psychological achievements. Table 1 is a description of the number of employees from several departments in a rattan unit.

\begin{tabular}{|c|c|c|c|c|c|c|c|}
\hline \multirow[t]{2}{*}{ Department } & \multicolumn{2}{|c|}{ Persistent } & \multicolumn{2}{|c|}{$\begin{array}{c}\text { Outsourcing By } \\
\text { Company }\end{array}$} & \multicolumn{2}{|c|}{$\begin{array}{c}\begin{array}{c}\text { Outsourcing By } \\
\text { Vendor }\end{array} \\
\end{array}$} & \multirow[t]{2}{*}{ Total } \\
\hline & Male & Female & Male & Female & Male & Female & \\
\hline Materials & & & 1 & 1 & & & 2 \\
\hline Quality Control & 1 & & 5 & & & & 6 \\
\hline Frame 1 & 1 & & & & 11 & & 12 \\
\hline Frame 2 & 1 & & & 1 & 9 & & 11 \\
\hline Frame 3 & 1 & & & & 10 & & 11 \\
\hline Decoration & 1 & & 1 & & 9 & & 11 \\
\hline Wicker & & & & 1 & 7 & 4 & 12 \\
\hline String & & & 1 & 2 & & 5 & 8 \\
\hline Sandpaper & & 1 & & 1 & & 16 & 18 \\
\hline Painting & & & 6 & & & & 6 \\
\hline Sanding & & 1 & & & & 19 & 20 \\
\hline Packing \& Checking & & & 3 & 3 & 2 & 1 & 9 \\
\hline Jock & & & 1 & & & 1 & 2 \\
\hline$R \& D+$ Designer & 2 & & & 2 & & & 4 \\
\hline Cleaning & & & 3 & & & & 3 \\
\hline Warehouse & 2 & & & & & & 2 \\
\hline Driver & 1 & & & & & & 1 \\
\hline Maintenance & 1 & & & & & & 1 \\
\hline Staff & & 6 & & & & & 6 \\
\hline Cooperation & & & & 2 & & & 2 \\
\hline Security & 12 & & & & & & 12 \\
\hline & 19 & 12 & 21 & 14 & 48 & 46 & 160 \\
\hline
\end{tabular}

Table 1: Production Department Unit Rattan of PT. Aneka Regalindo 2016 : The list of the amount of employee trouble across all departments in rattan unit of PT. Aneka Regalindo

Table 1 shows that the problem that occurred in the implementation of competency improvement is that the employees in the organisation of the company don't have equal opportunities to participate in the development of procedures to do with improving competency. This location was chosen because there was found to be many problems associated with competency issues. Based on preliminary observations made up of the obtained information, the problems relating to the competence, among others, include: 1.) some employees have relationship exclusively with the owner of the company, causing a mismatch between position and competence; 2.) accounting staff are not consulting scholars or experts of financial accounting; 3.) from within the production department, most employees were acquired from vocational experts but they are not supported by industry experts as well as businesses in the industrial field; 4.) security personnel do not have the experience or a certificate of education as security; 5.) some of the department supervisors graduated from senior high school and vocational high school, who otherwise did not have special competence in their field; 6.) about $60 \%$ of the employees do not come from an expert field, but it was based only on work experience so that the performance orientation could not reach the maximum yet.

\section{Research Problem}

Based on the background of the problems that have been mentioned above, the research problems can be used to formulate how the competency development models relate in terms of the performance orientation that can be used to improve the competency of the employees in PT. Aneka Regalindo.

\section{Purpose and Benefit}

The purpose of this study was to identify and describe the development of competency models in terms of performance orientation that can be used to improve the competency of employees of PT. Aneka Regalindo.

\section{Competency, Components and Advantage}

A person who is competent with the appropriate job skills are fast, intuitive and very rarely or never make mistakes [1]. Competency is defined as an attribute or characteristic required by a holder of office in order to carry out the office well. It could also mean the characteristics/traits of a person who is easily seen including knowledge, skills, and behaviour that allows for better performance [2].

Competency consists of the unique properties of each individual expressed in the process of interaction with others in a social context. It is not only limited to the specific knowledge, skills or standards of performance expected and the behaviour shown [3]. There are five components of the competency needed such as personal credibility, the ability to manage changes, the ability to manage culture, the delivery of human 
resource practices, and knowledge of the business [1]. There are several benefits of competency such as (1) Predictors of the success of the work; (2) Recruiting employees that are reliable; (3) The basis of assessment and development for the employee [4].

\section{Standards Aspect of Competency}

Personal credibility includes the individual's track record of success, such as being trusted, being able to instil confidence in others, mingling with key constituencies, demonstrating high integrity in performing their duties and responsibilities, asking important questions, having a brilliant idea that can take a risk right, being observational and having alternative business issues [5].

The ability to manage culture is a third competency needed for human resources. In this case, it includes several capabilities such as competency knowledge sharing across suborganisations within the organisation being limited (organisational boundaries). Second is the ability to fight the process of cultural transformation. Third is putting the desired culture in to specific behaviours. Fourth is competency challenging the status quo. Fifth is being able to recognise the desired culture to discover the company's business strategy and cultural frame in order to stimulate the employees. Sixth should be able to encourage the executives to behave consistently with the desired culture, and the last focuses on the internal culture to determine and meet the desires and needs of the external customer which will determine the success of a company, because without satisfaction of the external customer, efforts will be in vain [2].

In the delivery of the human resources practice, one of the various capabilities includes the ability to express verbal communication effectively, which can work with the manager to send a clear and consistent message to all involved in an organisation to achieve the agreed objectives, to facilitate the process of organisational restructuring, designing development programs that facilitate change, facilitating the design of internal communication, the ability to attract the right staff, being capable of designing the compensation system and facilitating the deployment of human resource information [2].
Knowledge of the business is where competency is specified further into the understanding of human resource practices, organisational structure, analysing competitors, financial management, marketing and sales, and computer information systems [6].

\section{Performance}

Performance is a concept that can create harmony in the workplace and can lead to an increased performance level in the individual employees in a company [7]. Performance is based on their hope embodied in the work and how the individual is trying hard to make it happen [8].

\section{The Types of Performance}

There are several types of employee performance, such as: (1) Instrumentally; in this approach, other types of employees see work as an end goal where employees are working for one reason which is to meet the needs of life everyday; (2) Solidaristic, which is the approach to performance orientation where every employee looking for a job is viewing it as not being as simple as the final destination, but as something to have relationships and social activities within. This is seen of as emotionally rewarding; (3) Bureaucratic, refers to everything that makes an employee optimise themselves to the work chosen. It is the things that are provided by the company where the employee works [8].

Performance orientation is a mental framework that aims to make people be able to interpret and respond to situations or events that they face [3]. Specifically, there are two kinds of performance orientation; named performance goals and performance learning. Performance can be classified into two: performance goal and learning performance [9].

\section{Interpretation Descriptive Study of Competency Development Model \\ To obtain a form of competency} development, a model from interviews and focus group discussion coupled with analytical methods such as an affinity diagram groups the results of the data collection that are homogeneity. Table 2 shows the mapping of the indicators and review concepts related to the components of the competency development model. 


\begin{tabular}{|c|c|c|}
\hline Indicator Concepts & Indicators of Observation & Component Description \\
\hline \multirow[t]{5}{*}{ Knowledge } & $\sqrt{ }$ & 1. Creativity \\
\hline & $\sqrt{ }$ & 2. Inovation \\
\hline & $\sqrt{ }$ & 3. Technology \\
\hline & $\sqrt{ }$ & 4. Thinking strategically \\
\hline & $\sqrt{ }$ & 5. Critical and analysis \\
\hline \multirow[t]{6}{*}{ Skill } & $\sqrt{ }$ & 1. Good resilience \\
\hline & $\sqrt{ }$ & 2. Communication \\
\hline & $\sqrt{ }$ & 3. Adaptability \\
\hline & $\mathrm{x}$ & 4. Management conflict \\
\hline & $\sqrt{ }$ & 5. Personal development \\
\hline & $\mathrm{x}$ & 6. Developing others \\
\hline \multirow[t]{5}{*}{ Attitude } & $\sqrt{ }$ & 1. Self-awareness \\
\hline & $\sqrt{ }$ & 2. Initiative \\
\hline & $\sqrt{ }$ & 3. Implement the vision and mission of personal and organization \\
\hline & $\sqrt{ }$ & 4. Concern for quality of productivity \\
\hline & $\sqrt{ }$ & 5. Conduct in work performance \\
\hline \multirow[t]{6}{*}{ Personal Credibility } & $\sqrt{ }$ & 1. Responsbility \\
\hline & $\sqrt{ }$ & 2. Building partnership and relationship \\
\hline & $\sqrt{ }$ & 3. Commitment and consistent \\
\hline & $\sqrt{ }$ & 4. Politic Intellegence \\
\hline & $\sqrt{ }$ & 5. Ability to influencing and negotiating \\
\hline & $\sqrt{ }$ & 6. Interpersonal skills \\
\hline \multirow[t]{6}{*}{ Ability to manage changes } & $\mathrm{x}$ & $\begin{array}{l}\text { 1. Thinking and solving any problems to reach the innovation } \\
\text { (changes) }\end{array}$ \\
\hline & $\mathrm{x}$ & 2. Management technology \\
\hline & $\mathrm{x}$ & 3. Management innovation \\
\hline & $\sqrt{ }$ & 4. Agent of change \\
\hline & $\sqrt{ }$ & 5. Learning continuously \\
\hline & $\sqrt{ }$ & 6. Organizational commitment \\
\hline \multirow[t]{6}{*}{ Ability to manage culture } & $\sqrt{ }$ & 1. Impact and influence \\
\hline & $\sqrt{ }$ & 2. Thinking analytically \\
\hline & $\mathrm{x}$ & 3. Anticipating issues \\
\hline & $\sqrt{ }$ & 4. Awareness of the organizational culture \\
\hline & $\sqrt{ }$ & 5. Integrity and honesty \\
\hline & $\sqrt{ }$ & 6. Managing organizational culture \\
\hline \multirow{6}{*}{$\begin{array}{l}\text { Delivery of human } \\
\text { resources practice }\end{array}$} & $\sqrt{ }$ & 1. Human resource management \\
\hline & $\sqrt{ }$ & 2. Looking for information \\
\hline & $\sqrt{ }$ & 3. Achieving the reliability of the work-expertise technically \\
\hline & $\sqrt{ }$ & 4. Assertiveness \\
\hline & $\sqrt{ }$ & 5. Establish interpersonal and team skills \\
\hline & $\sqrt{ }$ & 6. Oral communication \\
\hline \multirow[t]{5}{*}{ Knowledge of the business } & $\sqrt{ }$ & 1. Result-oriented of production and capacity \\
\hline & $\sqrt{ }$ & 2. Financial management \\
\hline & $\sqrt{ }$ & 3. Business management \\
\hline & $\sqrt{ }$ & 4. Profitability \\
\hline & $\sqrt{ }$ & 5. Ability to manage business \\
\hline
\end{tabular}

Table 2 : Primary Source 2017 : Indicator Concepts, Indicators of Observation, and Description of Components For Competency Development Model

\section{Research Method}

We used qualitative methods to determine how to find, collect, process and analyse the data from the research. The purpose of this approach is to obtain in-depth data, the data's meaning and understanding the phenomenon of what is experienced by the subjects holistically, by way of a description in the form of words and language, in a specific context that is natural using various scientific methods [10]. In this study, the researcher took the population that was the rattan unit employees of PT. Aneka Regalindo and the sampling technique used was purposive sampling. The sampling technique was chosen due to the particular consideration of both the traits and/or characteristics of the informants [11].

The informants are: 1.) Chairman; 2.) Vice Chairman; 3.) Manager HRD; 4.) Manager Production; 5.) Manager Quality Control; 6.) Manager PPIC; 7.) Supervisor HRD; 8.) Supervisor Production; 9.) Supervisor Quality Control; 10.) Supervisor PPIC; 11.) Ten employees of the Production Department. To obtain complete 
information in accordance with the focus of the research, we used data collection techniques including an interview, observation techniques, technical documentation, a literature study, and a focus group discussion as seen in Figure 1:

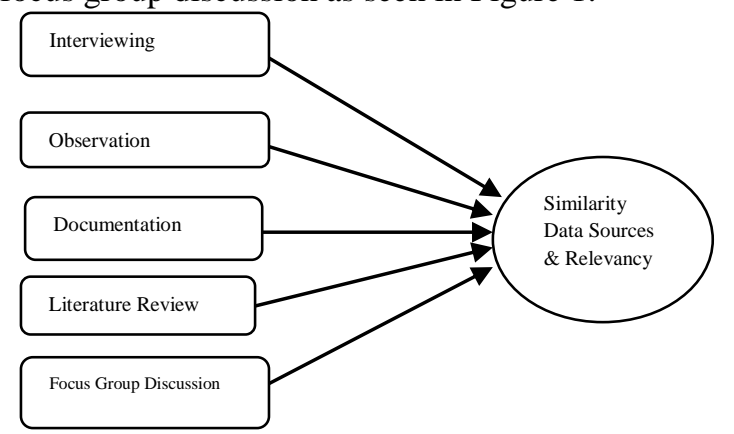

The model development include procedures such as: (1) specifying products; (2) theoretical study; (3) development planning; (4) initial model development; (5) model validation; and (6) the discovery of the final product [12]. Furthermore, we identified the 10 phases of the working procedures in the research and development models. Then it was simplified into 3 main phases based on the characteristics of the problems and the limits of the scope of research [13]. The three phases are: (1) the preliminary phase; (2) the development phase; and (3) the validation phase to get the final model/product.

Fig. 1 : Moleong 2007 : Data Collection Technical

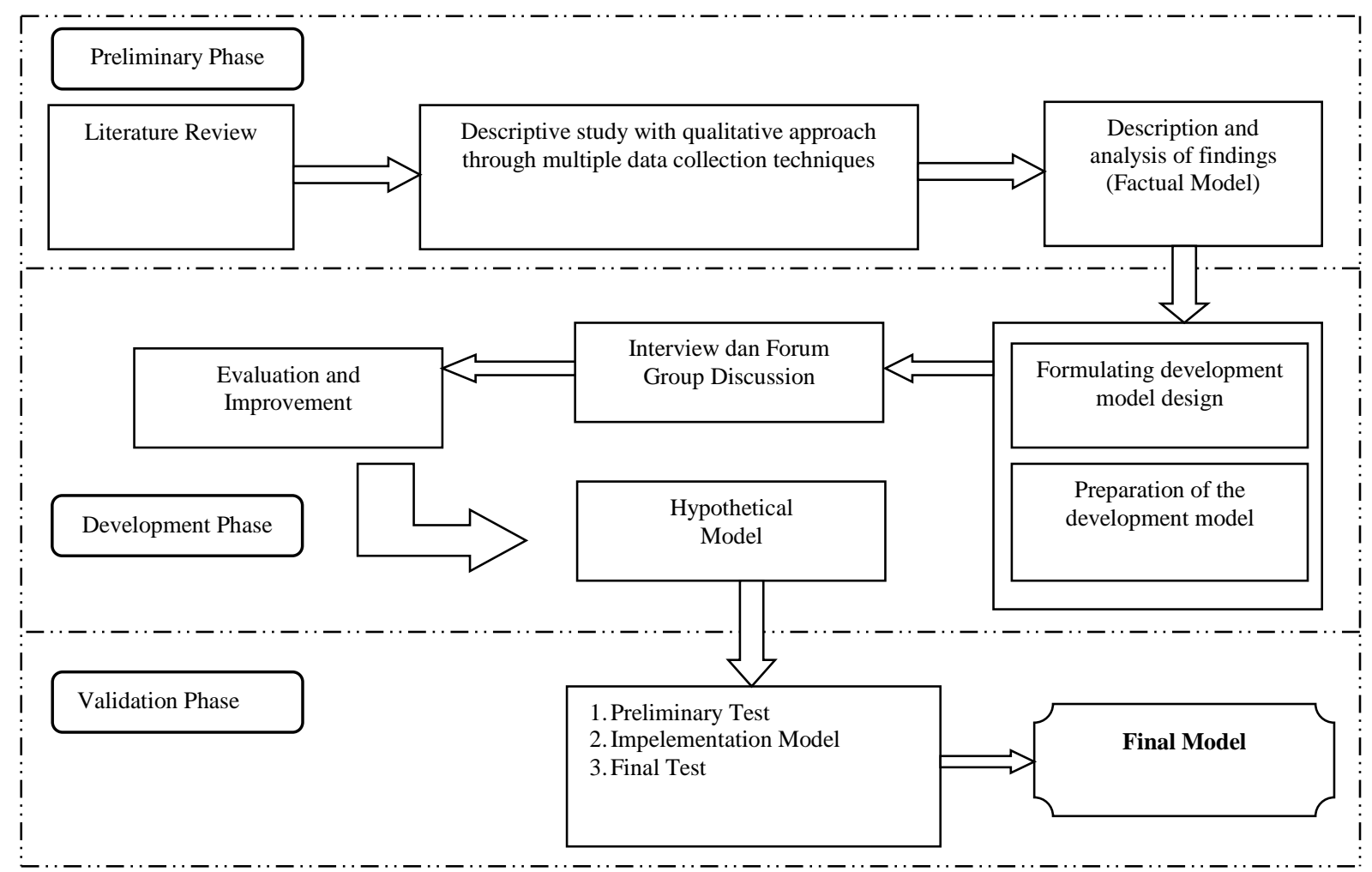

Fig. 2: Borg and Gall, 2007 : Phases of Research and Development

\section{Result and Conclusion}

The results are of the identification and implementation of the condition of the employees before and after implementation of the competency development model in terms of performance. The researcher found out many things such as:

a. Conceptualisation of the competency development model, departing from the values of the company's organisational culture that prefer the pattern of kinship that exists between employees and systematic performance. This has able to provide powerful inspiration in the conceptual framework underlying the competency development models in terms of performance orientation. The informants assume that a competency model is developed in according with their needs. This competency development model consists of three stages: 1 ) test of the research phase; 2) test of development and validation phase; 3) test of trial model phase.

b. The implementation of the competency development model, based on the results of the implementation trial conducted. The competency development model has been deemed appropriate to empowering employees in terms of performance. In the implementation phase, the results of the observation of the model tested at all stages shows that it is capable of making a positive contribution to 
increasing the employee's competency. The contributions have been in accordance with the employee's needs in order to improve and enhance the competency indicators accordingly

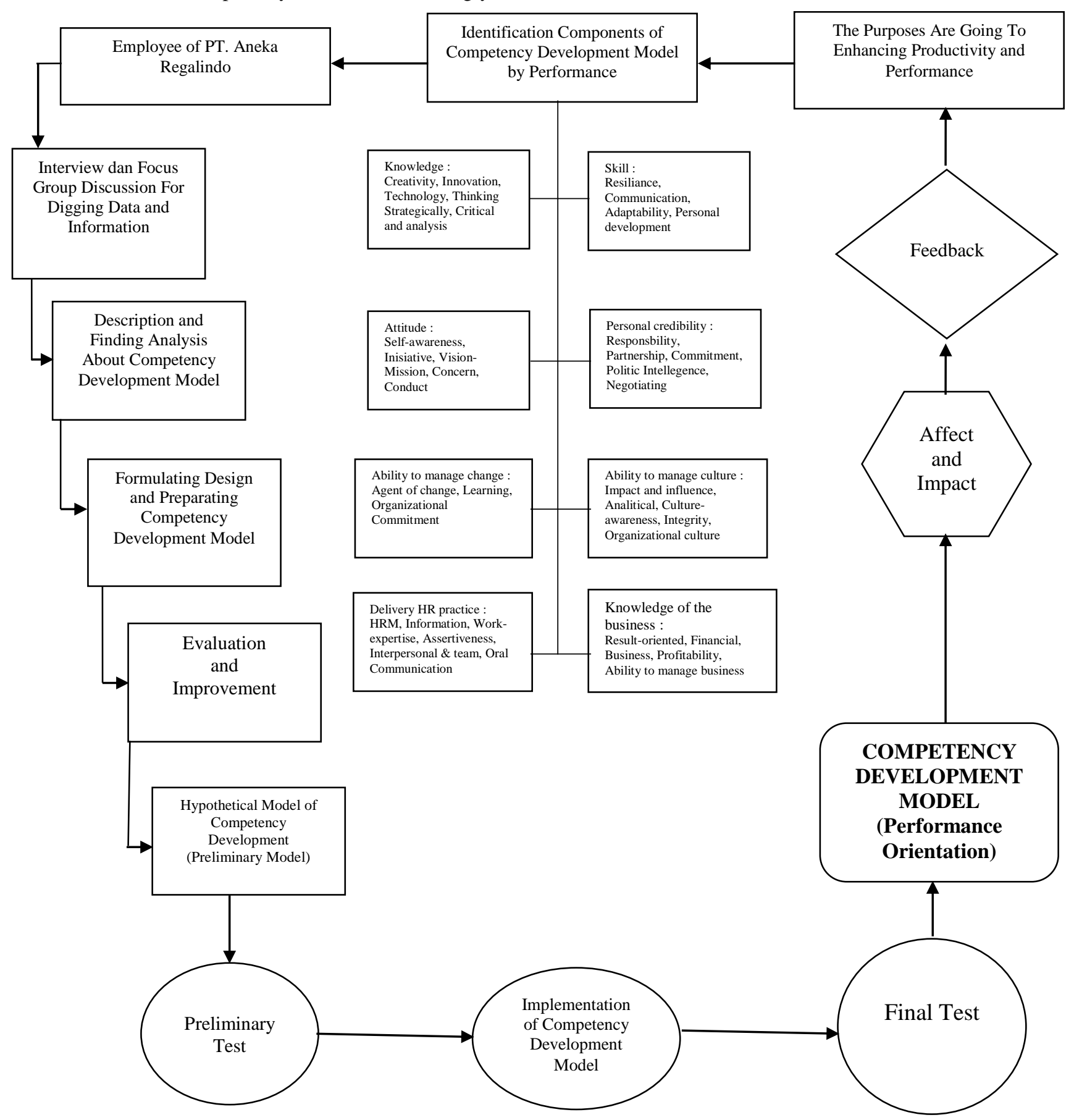

Fig. 3: Primary Data, 2017 : Competency Development Model Based On Performance Orientation

From the results of research conducted, it showed consistently that the implementation competency development model can improve the employee's competency which has a positive impact on improving performance. The construction of the models was built by looking at the indicators of the employee's competency mapping as an indigenous learning system. The process of the construction model is based on mapped in terms of performance, among others: knowledge, skill, and attitude. 


\section{References}

[2] Ahmad, R. (2010). Is Entrepreneurial Competency and Business Success Relationship Contingent Upon Business Environment? A Studi of Malaysian SMEs. International Journal of Entrepreneurial Behaviour and Research, 16 (3), 182-203.

[12] Borg, W.R. \& Gall, M. D. (2007). Applying Research: Research and Development Model. New York: Longman. Inc.

[8] Boulter N., Thompson, M. \& Hill, J. (2008). Developing Competencies Based On Core Business and Character. London: Bidlles, Ltd.

[7] Covey, S. R. (2010). Personality Development For Competency. European Journal of Human Resource. Vol. 1, pp. 23-37

[5] Endi, S. (2013). Entrepreneurial Characteristics and Competency as Determinants of Business Performance in SMEs. IOSR Journal of Business and Management. 7 (3), 2013, 31-38.

[6] Emadzade, M.A. (2012). Knowledge Management Capabilities and Organizational Performance. Interdisciplinary Journal of
Contemporary Research in Business, 3(11), pp. 20-32

[4] Gomes, F. C. (2008). Human Resource: Book For Business. Jakarta: Pranada Media.

[9] Mangkunegara, A. P. (2008). Perilaku Dan Budaya Organisasi. Bandung: Rafika Aditama.

[10] Moleong, L. J. (2007). Metode Penelitian Kuantitatif dan Kualitatif $R \& D$. Bandung: PT. Rosdakarya.

[3] Sanghi, S. (2007). The Handbook of Competency Mapping: Understanding, Designing and Implementing Competency Models in Organizations ( $\left.3^{\text {rd }} \mathrm{Ed}\right)$. New Delhi: Mohan Cooperative Industrial Area Mathura Road.

[1] Spencer, M. L. \& Spencer, M. S. (2010).: Models of Competency and Performance. New York : John Wiley \& Sons.

[11] Sugiyono. (2010). Metode Penelitian Kuantitatif, Kualitatif, Dan R\&I (Ed. Ke-2). Bandung: Alfabeta.

[13] Syamsudin, A. (2009). Psikologi Pendidikan dan Aplikasi. Bandung: Remaja Rosdakarya. 